\title{
CARDIOVASCULAR DISEASES AND COMPLICATION IN COVID-19
}

\section{KARDIOVASKULARNE BOLESTI I KOMPLIKACIJE U COVID-19}

\author{
Siniša Pavlović1,2
}

${ }^{1}$ Univerzitetski klinički centar Srbije, Pejsmejker centar "Prof. dr Milan Bane Đorđević", Beograd, Srbija

${ }^{2}$ Univerzitet u Beogradu, Medicinski fakultet, Beograd, Srbija

Correspondence: sinisa.pavlovic@med.bg.ac.rs

Keywords:

SARS-CoV-2, cardiovascular, thromboembolic
Abstract

From the late fall of 2019 until the beginning of 2020, SARS-CoV-2 infection is becoming the biggest global challenge of health systems worldwide. Characteristic of the encounter with the disease caused by COVID-19 was a certain wandering in the mechanisms of action of the virus, its consequences, and thus in therapy. Various manifestations of the disease confirm the assumption that it is a systemic infection with the respiratory system as an entry route. We were also faced with the fact that the SARS-CoV-2 virus has great implications for the cardiovascular system. Patients with cardiovascular risk factors, including male gender, advanced age, diabetes, hypertension, and obesity, as well as patients with established cardiovascular and cerebrovascular disease, have been identified as particularly susceptible populations with increased morbidity and mortality from COVID-19. The effects on the cardiovascular system are reminiscent of other diseases caused by this group of viruses. There are biochemical, electrocardiographic and echocardiographic confirmations of functional disorders. It is basically an immune response caused by tissue inflammation, which results in prothrombogenicity as the dominant and biggest problem, coupled with the highest risk of a possible bad outcome.

Being a systemic disease with numerous and different repercussions on the cardiovascular system, COVID-19 can lead to the appearance of all cardiovascular diseases that the patient did not have before, or to a significant worsening of the existing cardiovascular disease. The condition after the disease in most cases also means recovery, but great caution is needed due to possible time-distant complications. Since there is a high risk of death in the end, it is necessary to apply all available measures, especially in the field of prevention of thromboembolic complications, as a factor of the greatest risk of a bad outcome.
Pavlović S. MedPodml 2021, 72(3):65-69

(C)

The authors declare no conflicts of interest. doi:10.5937/mp72-33011

Editorial board: podmladak.med.bg@gmail.com e-ISSN: 2466-5525 


\section{Sažetak}

Od kasne jeseni 2019. godine, pa početkom 2020. godine infekcija SARS-CoV-2 postaje najveći globalni izazov zdravstvenih sistema širom sveta. Karakteristično za susret sa bolešću uzrokovanom COVID-19 bilo je određeno lutanje u mehanizmima delovanja virusa, njegovih posledica, a time i u terapiji. Različite manifestacije bolesti potvrđuju pretpostavku da se radi o sistemskoj infekciji sa respiratornim sistemom kao ulaznim putem. Virus SARS-CoV-2 pri tome ima velike implikacije na kardiovaskularni sistem. Pacijenti sa kardiovaskularnim faktorima rizika, uključujući muški pol, poodmaklo životno doba, dijabetes, hipertenziju i gojaznost, kao i pacijenti sa utvrđenom kardiovaskularnom i cerebro vaskularnom bolešću, identifikovani su kao posebno osetljive populacije sa povećanim morbiditetom i mortalitetom od COVID-19. Efekti na kardiovaskularni sistem po svemu podsećaju na druge bolesti izazvane ovom grupom virusa. O poremećajima funkcije postoje biohemijske, elektrokardiografske i ehokardiografske potvrde. U osnovi je upala tkiva izazvana imunim odgovorom, što za posledicu ima protrombogenost kao dominantni i najveći problem, skopčan sa najvećim rizikom mogućeg lošeg ishoda.

COVID-19 je sistemska bolest sa brojnim i različitim reperkusijama na kardiovaskularni sistem koja može dovesti do pojave svih kardiovaskularnih bolesti koje pacijent ranije nije imao, ili do značajnog pogoršanja postojeće kardiovaskularne bolesti. Stanje posle bo-

Ključne reči:

SARS-CoV-2,

kardiovaskularni, tromboembolijske lesti u većini slučajeva takođe znači i oporavak, ali potreban je veliki oprez zbog mogućih vremenski udaljenih komplikacija. S obzirom na to da na kraju postoji visok rizik od smrti, neophodno je primeniti sve raspoložive mere, posebno u oblasti prevencije tromboembolijskih komplikacija, kao faktora najvećeg rizika od lošeg ishoda.
The coronavirus disease 2019 (COVID-19), caused by severe acute respiratory syndrome coronavirus 2 (SARS-CoV-2) has led to a pandemic that has dramatically transformed the healthcare landscape around the world. Very soon, at the beginning of 2020, it has become the biggest global health care challenge worldwide. Despite rapid advances in medical technology in the past 30 years, the COVID-19 pandemic took significant toll in public health care across the globe. Due to myriad of clinical presentations, the initial encounter with the disease reminisced of "blind man and the elephant" allegory, with pieces of pathogenesis puzzle coming together along the path of constant and relentless work of thousands of medical workers and researchers. Although respiratory symptoms are the dominant trait of COVID-19, experience and initial research showed that it is a systemic disease, with major implications for cardiovascular system, as well. In time, this introduced several therapeutic protocols, but this learning through experience did not come without a cost. Patients with cardiovascular risk factors including male sex, advanced age, diabetes, hypertension and obesity, as well as patients with established cardiovascular and cerebrovascular disease, have been identified as particularly vulnerable populations with increased morbidity and mortality when suffering from COVID-19 (1). A study involving 5700 patients from New York City confirmed that the most common comorbidities were hypertension (56.6\%), obesity $(41.7 \%)$, diabetes $(33.8 \%)$, coronary artery disease $(11.1 \%)$, and congestive heart failure (6.9\%) (2). It was then confirmed that over $7 \%$ of patients and $22 \%$ of those with more severe forms of the disease have some form of myocardial damage (3). Diseases previously described as a consequence of coronavirus infections, such as severe acute respiratory syndrome (SARS) caused by severe acute respiratory syndrome coronavirus (SARS-CoV or SARS-CoV-1) and MERS (Middle East Respiratory Syndrome) also had their own cardiovascular manifestations. Mortality in these diseases was slightly over $10 \%$ for SARS, and over $30 \%$ for MERS, but the level of contagiousness was lower, so there was no spread of infection $(4,5)$. Hypotension, myocarditis, arrhythmias, and sudden cardiac death have been reported in cases of SARS infection (6). In addition to these, electrocardiographic changes, sub-clinical left ventricular diastolic impairment and troponin elevation were confirmed. Cases of myocarditis and heart failure have been confirmed in patients with MERS (7). In relation to these findings, and with confirmation in the clinical picture of patients, especially those with a lethal outcome, a post mortem analysis was performed. Autopsies of patients with COVID-19 infection revealed infiltration of the myocardium by interstitial mononuclear inflammatory cells (8). Increased cardiac biomarker levels, due to myocardial injury, were confirmed in these patients prior to death. The myocardial injury and the increased levels of biomarkers are likely associated with infection-induced myocarditis and ischemia (9). Moreover, in multivariable adjusted models, cardiac injury was significantly and independently associated with mortality (10). Elevated troponin $T$ levels due to cardiac injury were associated with significantly higher mortality. These patients were more likely to be men, older and with more comorbidities such as hypertension and coronary heart disease (11). Cardiac cell damage has resulted in a wide range of different heart rhythm disorders, from atrial premature beats, AV block of various levels, ventricular arrhythmias to sudden cardiac death. Severe COVID-19 infections are also potentially associated with cardiac arrhythmias, at least in part due to infection-related myocarditis (12). Follow-up of patients 
after the acute phase of COVID-19 confirmed that there was an increased cardiovascular risk over a longer period of time than expected. It is well established that in patients with severe pneumonia, hypercoagulability and systemic inflammatory activity can persist for a long period (13). A number of studies have confirmed that patients with a history of coronavirus infection often had hyperlipidemia, cardiovascular system abnormalities, or glucose metabolism disorders (7). Of course, in view of this, we must keep in mind the fact that a significant number of patients were treated with pulses of methylprednisolone, which could be the explanation for the long-term perturbation of lipid metabolism rather than a consequence of the infection itself (8).

Such a large number of clinical manifestations confirmed that COVID-19 is a systemic infection, but it also raised questions about the pathophysiological mechanisms that lead to such a wide range of changes.

What do we know so far about the causative agent COVID-19?

COVID-19 is caused by a novel beta-coronavirus, which is officially abbreviated as SARS-CoV2. Coronaviruses are enveloped, single-stranded ribonucleic acid (RNA) viruses with surface projections that correspond to surface spike proteins (14). It was soon confirmed that the virus attacks the cell via the angiotensin-converting enzyme 2 receptor (15). Binding of the SARS-CoV 2 spike protein to ACE2 facilitates virus entry into lung alveolar epithelial cells, where it is highly expressed, through processes involving cell surface associated transmembrane protein serine 2 (16). The RAS/ACE2 seems to be disrupted by SARS-CoV 2 infection, which likely plays a pathogenic role in severe lung injury and respiratory failure in COVID-19 (17). In addition to the lungs, ACE2 is highly expressed in human heart, vessels and gastrointestinal tract (18).

We have already pointed out that COVID-19 is a primary respiratory disease, but numerous patients also have cardiovascular disease, including hypertension, acute cardiac injury and myocarditis (19). At first, this was explained as a secondary consequence of lung disease, since acute lung injury itself leads to increased cardiac workload and can be problematic, especially in patients with pre-existing heart failure. In addition, the cardiovascular consequences were explained by the physiological role of RAS/ACE2 in the cardiovascular system and the fact that ACE2 is expressed in human heart, vascular cells and pericytes (20). A different approach to pathophysiological mechanisms has been imposed by the high frequency of coagulopathies in the population of inpatient and outpatient patients, including venous thromboembolism, myocardial infarction, and microvascular complications (21). Analysis of data from a large number of medical centers confirmed that $17.5 \%$ of hospitalized patients with COVID-19, who experienced a thrombotic event, died (22). Predictors of thrombosis, and thus a worse outcome, are the following: sepsis-induced coagulopathy score $>4$, underlying cardiovascular morbidity, D-dimer $>6 \mathrm{x}$ upper limit of normal, the stay in ICU with mechanical ventilation, advanced age $>75$ years, the use of pre hospitalization treat-dose anti coagulation appear, and obesity (23-25).

In these patients, hemostasis disorders were clinically registered, manifested as pulmonary microthrombi, with elevated levels of cardiac biomarkers, significant

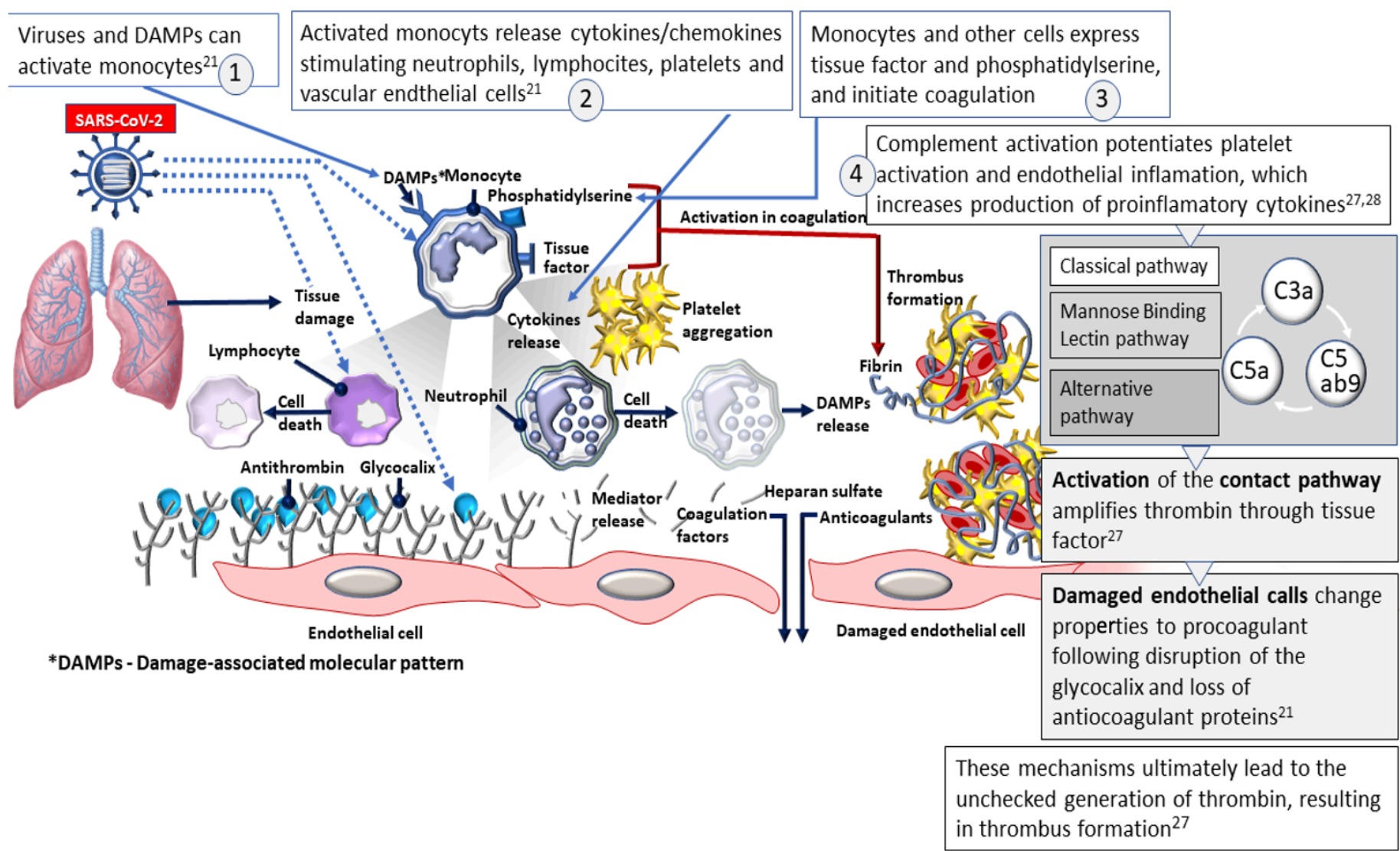

Figure 1. Modified by Pavlović S. according to Iba T. et al. (21), McFadyen JD. et al. (27) and Gerotziafas GT. et al. (28). 
increase in $\mathrm{D}$-dimer, fibrin degradation products and prothrombin time disorder, intravascular coagulopathy, platelet dysfunction and signs of myocardial damage (22).

It is especially important to point out that in patients with COVID-19 there may be certain specificity of coagulopathies such as: high prevalence of thrombotic complications in hospitalized and critically ill COVID-19 patients, unusual nature of thrombosis, in situ pulmonary embolism and pulmonary microthrombi with fibrin deposition in megakaryocytes, "breakthrough thrombosis" despite standard thromboprophylaxis (26).

The proposed mechanism of coagulation activation in COVID-19 is shown in figure 1.

All of the above is the reason why in preventing cardiovascular complications and poor outcome, it is insisted on monitoring parameters such as D-dimer. Among the first published results of the analysis from Wuhan was a cohort study that confirmed that in the group of patients who died, the level of D-dimer was many times higher than in the group of patients who survived (29). In addition, survival was significantly better in patients who received treatment-dose anticoagulation, even more significant in those who required mechanical ventilation. Bleeding events were similar between patients with and without treatment-dose anticoagulation (30).

Finally, it is important to point out that COVID-19 is a systemic disease with numerous and different repercussions on the cardiovascular system that can lead to the expression of all cardiovascular diseases that the patient did not have before, or significant worsening of existing cardiovascular diseases and cardiac dysfunction. The condition after the illness in most cases also means recovery, but great caution is needed due to possible time-distant complications. Since there is a high risk of death in the end, it is necessary to apply all available measures, especially in the field of prevention of thromboembolic complications, as a factor of the greatest risk of a bad outcome.

Literature

1. European Society of Cardiology. ESC Guidance for the Diagnosis and Management of CV Disease during the COVID-19 Pandemic (Internet). Brussels (Belgium). Updated on 10 June 2020. Available from: https://www.escardio.org/Education/ COVID-19-and-Cardiology/ESC-COVID-19-Guidance.

2. Richardson S, Hirsch J.S, Narasimhan M, Crawford J.M, McGinn T, Davidson K.W, et al. Presenting Characteristics, Comorbidities, and Outcomes Among 5700 Patients Hospitalized with COVID-19 in the New York City Area. JAMA. 2020; 323(20):2098.

3. Clerkin KJ, Fried JA, Raikhelkar J, Sayer G, Griffin JM, Masoumi A, et al. COVID-19 and cardiovascular disease. Circulation. 2020; 141(20):1648-55.

4. Chan-Yeung M, Xu RH. SARS: Epidemiology. Respirology. 2003; 8:S9-S14.

5. Mackay IM, Arden KE. MERS coronavirus: diagnostics, epidemiology and transmission. Virology journal. 2015; 12(1):1-21.

6. Yu CM. Cardiovascular complications of severe acute respiratory syndrome. Postgraduate medical journal, 2006; 82.964:140-4.

7. Xiong T.Y, Redwood S, Prendergast B, Chen M. Coronaviruses and the cardiovascular system: acute and long-term implications. Eur Heart J. 2020; 41(19):1798-800.
8. Xu Z, Shi L, Wang Y, Zhang J, Huang L, Zhang C, et al. Pathological findings of COVID-19 associated with acute respiratory distress syndrome. Lancet Respir Med. 2020; 8(4):420-2.

9. Madjid M, Safavi-Naeini P, Solomon SD, Vardeny O. Potential effects of coronaviruses on the cardiovascular system: a review. JAMA cardiology. 2020; 5(7):831-40.

10. Shi S, Qin M, Shen B, Cai Y, Liu T, Yang F, et al. Association of cardiac injury with mortality in hospitalized patients with COVID-19 in Wuhan, China. JAMA cardiology. 2020; $5(7): 802-10$

11. Nascimento J.H.P, Gomes B.F.O, Oliveira G.M.M. Cardiac Troponin as a Predictor of Myocardial Injury and Mortality from COVID-19. Arq Bras Cardiol. 2020; 115(4):667-8.

12. Wang D, Hu B, Hu C, Zhu F, Liu X, Zhang J, et al. Clinical characteristics of 138 hospitalized patients with 2019 novel coronavirus-infected pneumonia in Wuhan, China. Jama. 2020; 323(11):1061-9.

13. Clerkin KJ, Fried JA, Raikhelkar J, Sayer G, Griffin JM, Masoumi A, et al. COVID-19 and cardiovascular disease. Circulation. 2020; 141(20):1648-55.

14. Cui J, Fang L, Zheng-Li S. Origin and evolution of pathogenic coronaviruses. Nat Rev Microbiol. 2019; 17(3):181-92.

15. Li W, Moore M.J, Vasilieva N, Sui J, Wong S.K, Berne M, et al. Angiotensin-converting enzyme 2 is a functional receptor for the SARS coronavirus. Nature 2003; 426 (6965): 450-4.

16. Hoffmann M, Kleine-Weber H, Schroeder S, Kruger N, Herrler T, Erichsen S, et al. SARS-CoV-2 Cell Entry Depends on ACE2 and TMPRSS2 and Is Blocked by a Clinically Proven Protease Inhibitor. Cell 2020; 181(2):271-80e8.

17. Wu Y. Compensation of ACE2 Function for Possible Clinical Management of 2019-nCoV-Induced Acute Lung Injury. Virol Sin. 2020; 35(3):256-8.

18. Hamming I, Timens W, Bulthuis M.L, Lely A.T, Navis G, van Goor $\mathrm{H}$. Tissue distribution of ACE2 protein, the functional receptor for SARS coronavirus. A first step in understanding SARS pathogenesis. J Pathol. 2004; 203(2):631-7.

19. Chen C, Zhou Y, Wang D.W. SARS-CoV-2: a potential novel etiology of fulminant myocarditis. Herz. 2020; 45(3):230-2.

20. Chen L, Li X, Chen M, Feng Y, Xiong C. The ACE2 expression in human heart indicates new potential mechanism of heart injury among patients infected with SARS-CoV-2. Cardiovasc Res 2020; 116(6):1097-100.

21. Iba T, Jerrold H.L, Levi M, Thachil J. Coagulopathy in COVID-19. J Thromb Haemost. 2020; 18(9):2103-9.

22. Bikdeli B, Madhavan M, Jimenez D, Chuich T, Dreyfus I, Driggin E, et al. Global COVID-19 Thrombosis Collaborative Group, endorsed by the ISTH, NATF, ESVM, and the IUA, Supported by the ESC Working Group on Pulmonary Circulation and Right Ventricular Function COVID-19 and Thrombotic or Thromboembolic Disease: Implications for Prevention, Antithrombotic Therapy, and Follow-Up: JACC State-of-the-Art Review. J Am Coll Cardiol. 2020; 75(23):2950-73.

23. Tang N, Bai H, Chen X, Gong J, Li D, Sun Z. Anticoagulant treatment is associated with decreased mortality in severe coronavirus disease 2019 patients with coagulopathy. Journal of thrombosis and haemostasis. 2020; 18(5):1094-9.

24. Lodigiani C, Iapichino G, Carenzo L, Cecconi M, Ferrazzi P, Sebastian T, et al. Venous and arterial thromboembolic complications in COVID-19 patients admitted to an academic hospital in Milan, Italy. Thrombosis research. 2020; 191:9-14.

25. Klok FA, Kruip MJ, Van der Meer NJ, Arbous MS, Gommers DA, Kant KM, et al. Confirmation of the high cumulative incidence of thrombotic complications in critically ill ICU patients with COVID-19: an updated analysis. Thrombosis research. 2020; 191:148-50.

26. Spyropoulos AC, Weitz I. Hospitalized COVID-19 Patients and Venous Thromboembolism - A Perfect Storm. Circulation. 2020; 142:129-2.

27. McFadyen JD, Stevens H, Peter K. The emerging threat of (micro) thrombosis in COVID-19 and its therapeutic implications. Circulation research. 2020; 127(4):571-87. 
28. Gerotziafas GT, Catalano M, Colgan MP, Pecsvarady Z, Wautrecht JC, Fazeli B, et al. Guidance for the management of patients with vascular disease or cardiovascular risk factors and COVID-19: position paper from VAS-European Independent Foundation in Angiology/Vascular Medicine. Thrombosis and haemostasis. 2020; 120(12):1597-628.

29. Zhou F, Yu T, Du R, Fan G, Liu Y, Liu Z, et al. Clinical course and risk factors for mortality of adult inpatients with COVID-19 in Wuhan, China: a retrospective cohort study. The lancet. 2020; 395(10229):1054-62.
30. Paranjpe I, Fuster V, Lala A, Russak AJ, Glicksberg BS, Levin $\mathrm{MA}$, et al. Association of treatment dose anticoagulation with in-hospital survival among hospitalized patients with COVID-19. Journal of the American College of Cardiology. 2020; 76(1):122-4. 